encourages interventions, the primary disputing states may prefer ad hoc arbitration, where intervention is not possible. By summarily refusing interventions without granting a hearing, as it did in this case, justice is not seen to be done. ${ }^{35}$

\title{
CONCLUSION
}

The above comments look forward - to the issues that the case raises for the shaping of an international legal order for the future. I have intentionally not dealt with the underlying jurisdictional issues of the case, the factual controversies or the application of the law to the facts of the particular situation, but that silence should not be taken as agreement. The more general issues should attract scholarly discussion. They are not new. The creation of new international legal norms is a matter of general and continuing interest that transcends the boundaries of particular subfields of international law. The standards for the legitimate use of force have engaged that discussion since the inception of the debate over the definition of aggression and will continue to do so. For those concerned with the future role of the Court, the more procedural issues will also be of interest.

FRED L. MORRISON*

\section{The Other Shoe Falls: The Future of Article 36(1) JURISDICTION IN THE LIGHT OF NICARAGUA}

In the wake of the 1984 Judgment of the International Court on jurisdiction and admissibility issues in the Nicaragua case, ${ }^{1}$ the United States reviewed the utility and desirability of continued participation in the optional jurisdictional regime established by Article 36(2) of the Statute of the International Court of Justice. ${ }^{2}$ The Executive concluded essentially that the experiment initiated by the regime neither had succeeded nor was likely to succeed in the future; that its subscription was ragged and asymmetrical in terms of world politics; that the Court, the custodian of this mode of jurisdiction, had adopted new theories of interpretation that were inconsistent, in the U.S. view, with the thrust of the provision; that the Court itself had changed; and that, in sum, continued United States participation would dis-

\footnotetext{
${ }^{35}$ See Sztucki, Intervention under Article 63 of the ICJ Statute in the Phase of Preliminary Proceedings: The "Salvadoran Incident," 79 AJIL 1005 (1985); Chinkin, Third-Party Intervetition before the International Court of Justice, 80 AJIL 495 (1986).

* Professor of Law, University of Minnesota. The author was one of the counsel for the United States in the jurisdictional phase of the case, but did not participate in the case with respect to the merits. The opinions expressed here are solely those of the author and do not represent any official view of the United States Government or of the Department of State.

${ }^{1}$ Military and Paramilitary Activities in and against Nicaragua (Nicar. v. U.S.), Jurisdiction and Admissibility, 1984 ICJ REP. 392 (Judgment of Nov. 26). For the text of the U.S. Statement on withdrawal from the case, see DEP'T ST. BuLL., No. 2096, March 1985, at 64, reprinted in 24 ILM 246 (1985).

${ }^{2}$ Declaration of Aug. 14, 1946, 61 Stat. 1218, TIAS No. 1598, 1 UNTS 9.
} 
criminate against United States interests while contributing nothing to world order. ${ }^{3}$ Accordingly, on October 7, 1985, the Secretary of State informed the Secretary-General of the United Nations that the United States was terminating, in accord with the terms of its Declaration and the provisions of the Statute, its adherence to the optional regime under Article 36(2) of the ICJ Statute. ${ }^{4}$

The U.S. response addressed national policy with regard to the Court's jurisdiction under Article 36(2). But the Judgment of November 26, 1984 had rested jurisdiction on both paragraphs 1 and 2 of Article $36 .{ }^{5}$ Nicaragua, it will be recalled, had belatedly invoked Article XXIV of the 1956 Nicaragua-United States Treaty of Friendship, Commerce and Navigation (the FCN Treaty). ${ }^{6}$ Paragraph 2 of that provision provides: "Any dispute between the Parties as to the interpretation or application of the present Treaty, not satisfactorily adjusted by diplomacy, shall be submitted to the International Court of Justice, unless the Parties agree to settlement by some other specific means." In the 1984 phase, the Court simply concluded that "there can be no doubt that, in the circumstances in which Nicaragua brought its Application to the Court, and on the basis of the facts there asserted, there is a dispute between the Parties, inter alia, as to the 'interpretation or application' of the $[\mathrm{FCN}]$ Treaty." 8

Article $\operatorname{XXI}(1)(d)$ of the Treaty removes virtually all the key items in Nicaragua's Application from the jurisdiction of the Court. ${ }^{9}$ It provides, in relevant part, that " $[t]$ he present Treaty shall not preclude the application of measures: . . . (d) necessary to fulfill the obligations of a Party for the maintenance or restoration of international peace and security, or necessary to protect its essential security interests . . . "10 This provision was not mentioned by the Court. Though Article $\operatorname{XXIV(1)~as~well~as~customary~}$ international law prescribes negotiation as a prerequisite to the unilateral initiation of adjudication, the Court found that Nicaragua had discharged that requirement in substance, if not in form. ${ }^{11}$

In its Judgment on the merits of June $27,1986,{ }^{12}$ the Court made certain adjustments and retrofittings in its jurisdictional decision. It went through the motions of qualifying a theretofore rather dismissive treatment of the multilateral treaty reservation in the United States optional Declaration. ${ }^{18}$

\footnotetext{
'See generally Dep't of State Press Statement, 24 ILM 1743 (1985).

1 See Contemporary Practice of the United States, 80 AJIL 163-65 (1986).

${ }^{5} 1984$ ICJ REP. at 442, para. 113.

${ }^{6} I d$. at 426-27, para. 80. See also Separate Opinion of Judge Oda, id. at 472, 472.

${ }^{7}$ Treaty of Friendship, Commerce and Navigation, Jan. 21, 1956, Nicar.-U.S., 9 UST 449, TIAS No. 4024, 367 UNTS 3 (entered into force May 25, 1958).

${ }^{8} 1984$ ICJ REP. at 428, para. 83.

${ }^{9}$ See Dissenting Opinion of Judge Schwebel, $i d$. at 558, 635; see also Reisman, Has the International Court Exceeded its Jurisdiction?, 80 AJIL 128, 130-31 (1986).

${ }^{10}$ Treaty of Friendship, Commerce and Navigation, supra note 7.

11 1984 ICJ REP. at 428, para. 83.

${ }^{12}$ Military and Paramilitary Activities in and against Nicaragua (Nicar. v. U.S.), Merits, 1986

ICJ REP. 14, 38, para. 56 (Judgment of June 27).

is 1984 ICJ REP. at 425-26, paras. 75-76.
} 
But this was, in fact, a démarche in appearance only, as the Court then proceeded to declare that the customary law and conventional law invoked in the case were identical. ${ }^{14}$ The Court confirmed its holding of jurisdiction allegedly established under Article 36(1) of the Statute by the FCiN Treaty. ${ }^{15}$ It brushed aside the manifest exclusions in Article XXI(I)(d) in a single brief paragraph, in an argument consisting entirely of a superficial comparison between the text in the Treaty and a comparable text in the Gerteral Agreement on Tariffs and Trade. ${ }^{16}$ Moreover, it substantially expanded the ambit of the jurisdictional clause of the Treaty by interpreting the Treaty broadly, ${ }^{17}$ even reaching "implied" matters that also became subject to that clause. ${ }^{18}$ In effect, virtually anything "unfriendly," even were it otherwise within the pale of lawful international action, was rendered unlawful because this was a treaty of "friendship."

It is not the purpose of this Note to criticize the reasoning or the quality of judgment of the Court in this matter. The reader may find a range of views and cogent analyses amid the dissenting opinions. ${ }^{20}$ This Note examines the implications of the Judgment with regard to the extensive United States practice of using the Article 36(1) mode of jurisdiction and to ask whether the Judgment of June 27,1986 requires a reconsideration of U.S. attitudes.

\section{I.}

The Statute of the International Court of Justice provides for both advisory and contentious jurisdiction. ${ }^{21}$ In its advisory mode, the Court acts as a type of international constitutional tribunal ${ }^{22}$ and as a cour de cassation for international organizations that have been authorized to state questions to it. ${ }^{23}$

In its contentious jurisdictional mode, the Court resolves issues between states. These latter disputes may be referred to the Court in one of three ways. One of these, the optional regime (Article 36(2)), is a type of aleatory jurisdiction, in which states deposit general declarations with the SecretaryGeneral of the United Nations about the matters they are willing to adjudicate with another state making a similar declaration. Thereafter, a declaring state may initiate a case unilaterally against any other comparably declaring state without securing its special consent to the adjudication and without invoking an independent treaty clause. Article 36(2) jurisdiction is an innovative and experimental form, made possible by the continuity of the

\footnotetext{
14 I986 ICJ REP. at 92 ff., para. 172 et seq.

${ }^{16} I d$. at 116 , para. 222.

${ }^{18} I d$. at 138, para. 276.

${ }^{19} \mathrm{Cf}$. id. at $136-37$ and 138 , paras. 273 and 275.

${ }^{20}$ See especially the Dissenting Opinions of Judges Oda and Schwebel, id. at 212 and 259 , respectively.

${ }^{21}$ Art. 36, Statute of the International Court of Justice, ICJ ACTS AND DOCUMENTS, No. 4

${ }_{22}$ See, e.g., Certain Expenses of the United Nations (Article 17, paragraph 2, of the Charter), 1962 ICJ REP. 151 (Advisory Opinion of July 20).

${ }^{23}$ See, e.g., Application for Review of Judgement No. 273 of the United Nations Administrative Tribunal, 1982 ICJ REP. 325 (Advisory Opinion of July 20).
} (1978). 
International Court and its predecessor, the Permanent Court. But it has rarely been used and, in the light of the United States withdrawal and subsequent events, will probably decline further.

The more durable forms of the Court's jurisdiction are essentially a continuation of traditional arbitral forms. Article 36(1) provides: "The jurisdiction of the Court comprises all cases which the parties refer to it and all matters specially provided for in the Charter of the United Nations or in treaties and conventions in force." Article 36(1) contemplates two modes of engaging the contentious jurisdiction of the Court. One, by special agreement ("all cases which the parties refer to it"), may be called "special agreement jurisdiction." The other, comprising general agreements contemplating disputes within or about particular treaty regimes ("all matters specially provided for . . . in treaties and conventions in force"), may be referred to as "treaty-based jurisdiction."

II.

The United States is a major consumer of treaty-based jurisdiction under Article 36(1); according to the most recent ICJ Yearbook, Article 36(1) jurisdiction is incorporated in some 35 bilateral treaties to which the United States is party ${ }^{24}$ Moreover, the Senate is currently considering two more treaties that will incorporate the Court's treaty-based jurisdiction. ${ }^{25}$ The United States also participates in a large number of multilateral treaties that incorporate Article 36(1) jurisdiction. ${ }^{26}$ Even after the termination of Article 36(2) jurisdiction, the Department of State apparently continued to view Article 36(1) treaty jurisdiction as a desirable and important form of dispute resolution in treaties with commercial or other limited subject matter.

The doctrine of limited subject matter jurisdiction in these treaties is an important feature of their attractiveness and is central to decisions to use the International Court. The United States, like all other governments, views adjudication as only one of a number of facultative options available to states for the resolution of their disputes. In the absence of an affirmative choice by a state, adjudication in international law is not mandatory. ${ }^{27}$ Some states lawfully refuse to adjudicate anything. Others agree to selected matters. A state is entitled to refuse to agree in advance to either a treaty-based or a special agreement invitation to adjudicate matters that it thinks would be better treated in other modes of dispute resolution. In much the same way that many declarations made under Article 36(2) carefully and lawfully circumscribe the matters that the declaring state wishes to submit to the jurisdiction of the Court, clauses within treaties that establish jurisdiction under

24 1984-1985 ICJ Y.B. 102-18. For a list of the FCN treaties, see also List of Treaties of Friendship, Commerce and Navigation, 1980 ICJ Pleadings (United States Diplomatic and Consular Staff in Tehran) 233-34 (Ann. 51 to U.S. Memorial).

${ }^{25}$ Trademark Registration Treaty, S. EXEC. Doc. H, 94th Cong., Ist Sess. (1975); Vienna Convention on the Law of Treaties, S. ExEC. Doc. L, 92d Cong., 1st Sess. (1971).

${ }^{26}$ 1984-85 ICJ Y.B., supra note 24.

${ }^{27}$ But cf. Corfu Channel Case, Preliminary Objection, 1948 ICJ REP. 15, 27 (Judgment of Mar. 25). 
Article 36(1) are designed to operate only for those matters that the treaty parties are explicitly agreeing to submit. This "presumption of conffinement," so to speak, is basic to the use of the treaty-based mode.

The presumption of confinement was a central and explicit consideration in U.S. decisions to use the International Court in the growing genre of FCN treaties. To cite an example: a State Department memorandum dealing with the dispute settlement provisions of a particular FCN treaty, which had already been pleaded before the Court, expresses the presumption unequivocally:

The compromissory clause . . . is limited to questions of the interpretation or application of this treaty; i.e., it is a special not a general compromissory clause. It applies to a treaty on the negotiation of which there is voluminous documentation indicating the intent of the parties. This treaty deals with subjects which are common to a large number of treaties, concluded over a long period of time by nearly all nations. Much of the general subject-matter-and in some cases almost identical language - has been adjudicated in the courts of this and other countries. The authorities for the interpretation of this treaty are, therefore, to a considerable extent established and well known. Furthermore, certain important subjects, notably immigration, traffic in military supplies, and the "essential interests of the country in time of national emergency", are specifically excepted from the purview of the treaty. In view of the above, it is difficult to conceive how Article XXVIII (the dispute resolution clause in the FCN treaty with China) [the treaty on which the memorandum is based], could result in this Government's being impleaded in a matter in which it might be embarrassed. ${ }^{28}$

Another State Department memorandum on provisions in commercial treaties relating to the International Court addressed the same issue:

This paper . . . points out a number of the features which in its view make the provision satisfactory . . . These include the fact that the provision is limited to differences arising immediately from the specific treaty concerned, that such treaties deal with familiar subjectmatter and are thoroughly documented in the records of the negotiation, that an established body of interpretation already exists for much of the subject-matter of such treaties, and that such purely domestic matters as immigration policy and military security are placed outside the scope of such treaties by specific exceptions. ${ }^{29}$

Both memoranda were pleaded to the Court in the U.S.-Iranian case and were reproduced in Judge Schwebel's dissent to the merits decision. ${ }^{30}$ It is quite clear from these memoranda, and, indeed, from the concerns of any government contemplating adjudication, that the incorporation of Article 36(1) jurisdiction in American FCN treaties was premised on the assumption

\footnotetext{
${ }^{28}$ Memorandum on Dispute Settlement Clause in Treaty of Friendship, Commerce and Navigation with China (n.d.), reproduced in 1980 ICJ Pleadings, supra note 24, at 234, 235 (Ann. 52 to U.S. Memorial).

${ }^{29}$ Dep't of State, Memorandum on Provisions in Commercial Treaties relating to the International Court of Justice (n.d.), reproduced in 1980 ICJ Pleadings, supra note 24, at 236, 237.

${ }^{30} 1986$ ICJ REP. at 307-08, para. 101.
} 
that such jurisdiction would be confined to the explicit terms of the treaty. Certain subject matter deemed to be of special domestic concern and, in particular, matters of military security were not, in the U.S. view, any part of the jurisdictional bargain. Indeed, had the Court in Nicaragua engaged in an international legal interpretation of the FCN Treaty even faintly approximating what is prescribed in Article 31 of the Vienna Convention on the Law of Treaties, it would have found it impossible to ignore this manifest expectation.

III.

The Judgment of June 27, 1986 has effectively shattered key elements of the presumption of confinement. The Court reaffirms its earlier decision of seisin under the FCN Treaty ${ }^{31}$ and then proceeds, as mentioned, to dispose of the restrictive clause in the Treaty in a single paragraph and in a procedure that hardly qualifies as a paragon of interpretation. ${ }^{32}$ The Court concedes that the effect of Article XXI of the FCN Treaty is to reserve certain matters from the Court's jurisdiction, but holds that the determination of whether a matter is excluded is not within the unilateral competence of the state party. It is to be decided by the Court. ${ }^{33}$ In making that determination, the Court may assume that the measures in question are related to the essential security interests of the state concerned, but even then it will determine "whether the risk run by these 'essential security interests' is reasonable, and secondly, whether the measures presented as being designed to protect these interests are not merely useful but 'necessary'."34

One key element in the presumption of confinement is thus terminated. While the United States may have thought that the insertion of words in Article XXI of the Nicaragua-U.S. FCN Treaty and comparable words in the other treaties of this genre effectively excluded military matters, it now learns that the prevailing theory of jurisdiction holds that these words are no more than an initial claim by the United States that will be tested by the Court in terms of its own view of their contextual necessity and reasonableness.

A second element of the presumption of confinement concerns explicit subject matter. The memoranda of the United States considered above indicate clearly that it was assumed that only matters that were explicitly within the four corners of the treaty in question and not reserved were to be subject to the jurisdictional clause. The Court, however, develops a theory of implication: "there are certain activities of the United States which are such as to undermine the whole spirit of a bilateral agreement directed to sponsoring friendship between the two States parties to it."35 The Court extends this notion of implication in the following paragraph:

A State is not bound to continue particular trade relations longer than it sees fit to do so, in the absence of a treaty commitment or other

"See note 15 supra and accompanying text.

${ }^{32}$ See note 16 supra and accompanying text.

"See note 17 supra and accompanying text.

34 I986 ICJ REP. at 117, para. 224.

${ }^{55}$ Id. at 138 , para. 275 . 
specific legal obligation; but where there exists such a commitment, of the kind implied in a treaty of friendship and commerce, such an abrupt act of termination of commercial intercourse as the general trade embargo of 1 May 1985 will normally constitute a violation of the obligation not to defeat the object and purpose of the treaty. ${ }^{915}$

Thus, a second part of the presumption of confinement on which the jurisdictional clauses of United States FCN treaties have rested has been shattered.

IV.

Students of international law are inclined to study the problem of the jurisdiction of the International Court of Justice from a developmental perspective. More jurisdiction is better; decisions that enhance jurisdiction are the most worthy of applause. The consumers of international acljudication, governments and, more specifically, their international legal advisers, necessarily look at jurisdiction from a different angle. Because adjudication in international law is only one of a number of optional dispute resolution mechanisms, legal advisers must consider its appropriateness for their government in terms of the nature of the dispute, the attitude of the potential adversary with regard to adjudication, the alignments of judges on the Court, the extent to which the countries from which they come have critical interests in the potential dispute or parallel interests in cognate disputes, and so on. Because adjudication has certain properties that, in different contexts, may discriminate in favor of or against one of the parties, responsible legal advisers must decide carefully which bilateral matters should be made subject to an adjudicative jurisdictional clause and which should be reserved for other dispute-resolving modalities. That thoroughly legitimate national policy decision is meaningful only if the presumption of confinement operates and is interpreted in good faith. Nicaragua has cast this essential condition into doubt.

The question the United States must urgently address is whether, all things considered, it can afford voluntarily to subject itself to this essentially new regime. Variants of the "Portuguese Gambit" have been examined in the context of Article 36(2) are possible in jurisdictional clauses under Article 36(1). Changes of government and international political alignment in the other treaty partners may make jurisdictional clauses attractive political instruments for new governments to use against the United States in matters only distantly related to the FCN treaty or to the intentions of the parties; this has been rendered relatively easy, as the Court is apparently willing to introduce a great deal under the hardly uncommon term of international political parlance, "friendship." In less extreme cases, moderate governments may find it useful to develop ICJ cases that exceed the U.S. understanding of the confined jurisdictional clause, for

\footnotetext{
${ }^{36}$ Id., para. 276 (emphasis added). One may note that the Court is quite wrong here on the law. See Dissenting Opinion of Judge Oda, id. at 249-50, para. 80.

${ }^{37}$ W. M. REISMaN, Nullity and Revision: THE REview and ENForcement OF INTERNATIONAL JUDGMENTS AND AWARDS 379-83 (1971).
} 
bargaining purposes or to assuage an exigent domestic constituency to whom the issue may be of concern.

That contingencies such as these are not the products of a feverish imagination is confirmed by the case brought by Nicaragua. That the International Court is willing to reach out and accept such cases under innovative conceptions of its jurisdiction is now twice confirmed. In view of these developments, the United States would do well to undertake reconsideration of its wide-ranging use of the Article 36(1) mode of jurisdiction, before there are unpleasant surprises.

W. Michael ReismaN*

\section{Le Peuple, C'Est moi! The World Court AND HUMAN RIGHTS}

This essay examines the discussion of human rights and domestic jurisdiction by the International Court of Justice in the Nicaragua case. ${ }^{1}$ Independently of the final verdict about the lawfulness of U.S. help to the contras under principles of either self-defense or humanitarian intervention, the Court's views on the relationship amiong human rights, domestic jurisdiction and intervention are wrong in law. Furthermore, the philosophical assumptions of the Judgment are profoundly disturbing. For the reasons set forth below, I submit that the Court's approach embodies a backward view of international law and justice that was totally unnecessary to the resolution of the case.

The Court discussed the U.S. contention that the Government of Nicaragua had breached commitments to the Nicaraguan people, to the Organization of American States and to the United States with regard to Nicaraguan domestic policies. ${ }^{2}$ These included "questions such as the composition of the government, its political ideology and alignment, totalitarianism [and] human rights." The Court then made the following general statement:

[These] questions . . . are questions of domestic policy. The Court would not therefore normally consider it appropriate to engage in a verification of the truth of assertions of this kind . . . . A State's domestic policy falls within its exclusive jurisdiction, provided of course that it does not violate any obligation of international law. Every State possesses a fundamental right to choose and implement its own political, economic and social systems. Consequently, there would normally be

\footnotetext{
* Professor of Law, Yale University; Board of Editors.

${ }^{1}$ Military and Paramilitary Activities in and against Nicaragua (Nicar. v. U.S.), Merits, 1986 ICJ RE.P. 14 (Judgment of June 27). I do not address here the legality of the actions undertaken by the United States, especially those involving the use of force for human rights purposes.

${ }^{2} 1986$ ICJ REP. at 130-35, paras. 257-69. For Congress's formal findings that Nicaragua had breached its human rights obligations, see H.R. REP. No. 237, 99th Cong., 1st Sess. 6373 (1985), reproduced in pertinent part in id. at 90-92, paras. 169-70.

\$1986 ICJ REP. at 130, para. 257.
} 